\title{
Efficacy of different herbicides for controlling narrow leave weeds in wheat - crop at different locations under adaptive research zone Sheikhupura
}

Muhammad Shahbaz ${ }^{1}$, Sher Muhammad ${ }^{2 *}$, Faqir Ahmad ${ }^{3}$, Mehreen Anwar ${ }^{2}$, Muhammad Sajjad ${ }^{4}$, Muhammad Riaz ${ }^{3}$, Ghulam Nabi ${ }^{5}$ and Masaud Qadir Waqar 6

1. Adaptive Research Farm Sheikhupura, Punjab-Pakistan

2. Department of Bioinformatics and Biotechnology, Govt. College University Faisalabad-Pakistan

3. Pest warning and Quality control of Pesticides, Sheikhupura-Pakistan

4. Pest warning and Quality control of Pesticides, Pattoki, Kasur-Pakistan

5. Vegetable Research Sub-Station, Sheikhupura-Pakistan

6. Director of Agriculture (Adaptive Research) Punjab-Pakistan

*Corresponding author's email: sher1325@ hotmail.com

Citation

Muhammad Shahbaz, Sher Muhammad, Faqir Ahmad, Mehreen Anwar, Muhammad Sajjad, Muhammad Riaz, Ghulam Nabi and Masaud Qadir Waqar. Efficacy of different herbicides for controlling narrow leave weeds in wheat crop at different locations under adaptive research zone Sheikhupura. Pure and Applied Biology. Vol. 6, Issue 2, pp525-531. http://dx.doi.org/10.19045/bspab.2017.60053

\begin{tabular}{llll}
\hline \hline Received: 22/12/2016 & Revised: 29/03/2017 & Accepted: 02/04/2017 & Online First: 04/04/2017 \\
\hline
\end{tabular}

\section{Abstract}

Field experiment was conducted at three locations i.e. Adaptive Research Farm and two at farmers field during Rabi 2014-15 under ecological zone of Adaptive Research Farm Sheikhupura to study the efficacy of different post emergent herbicides against narrow leave weeds. The experiment was carried out in randomized complete block design (RCBD) with three repeats. Present study comprised of five treatments including control. The treatments comprised of Axial (penoxadin), Exit (clodinofop propargyl), Brake (fenoxaprop-p-ethyl), Proton (Isoproturon) and weedy check. The data were recorded on Plant height at maturity $(\mathrm{cm})$, no. of grains per spike, spike length $(\mathrm{cm})$, weed density $\mathrm{m}^{-2}, 1000$ grains weight $(\mathrm{g})$, and grain yield $(\mathrm{t}$ $\mathrm{ha}^{-1}$ ). All treatments of herbicide significantly control the weeds causing significant reduction in weed mass and also improved the grain yield significantly in comparison with the check at three locations. Highest death of weeds (96.12, 97.09 and $98.95 \%)$ and with maximum grain yield of $2846.7,3320.0$ and $3300.0 \mathrm{~kg} \mathrm{ha}^{-1}$ which is $19.6,39.6$ and $39.9 \%$ higher than weedy check were recorded in the penoxadin treated plot at three locations respectively. In the weedy check the weed density was 51, 126 and 127 weeds $\mathrm{m}^{-2}$ with grain yield 2380, 2376 and $2358 \mathrm{~kg} \mathrm{ha}^{-1}$ at three locations respectively.

Keywords: Wheat; Wheat weed density; Yield; Yield components; Herbicides 


\section{Introduction}

Wheat (Triticum aestivum L.) is a major player in world food security and for a sustainable food supply. It is the major staple food of Pakistan and meets the major nutrition requirements. It also meets the food requirement for livestock and poultry. Being an important cereal crop and is gaining popularity all over the world and especially in Pakistan. Due to increase in population and food prices, higher yield of the wheat can play a vital role in stabilizing the food prices directly or indirectly. Management of many factors can significantly contribute in increasing the grain yield of wheat in Pakistan. Among these factors, weed management is an important factor. In Pakistan wheat crop grown on an area of 9250 thousand hectare and it contributed in total production was 25478 thousand ton during 2014-15 [1]. While in the Punjab province the area under wheat crop was 6979.48 thousand hectare and its production remained 19282.0 thousand ton during 2014-15. The average yield of wheat in Pakistan is $2714 \mathrm{~kg} / \mathrm{ha}$, that is too low as compared to other highly developed wheat producing countries of the world.

Weeds cause considerable losses to production of crops that are economically more essential than fungi, insects and other pest organisms in many situations $[2,3]$. It was reported that the main goal of managing weed population is to keep the weed population at a satisfactory level rather than to keep the crop completely free of weeds [4]. Weed management enhances the cost of production of crops and thus it is very necessary to adopt such methods which could decrease not only the cost of production but also save labor and time. To manage weeds to an acceptable level, scientists adopt various methods among them the chemical control is one of the best methods to eliminate the weeds density, which is being given attention in recent agriculture [5]. Follwing narrow leaved weeds like Avena fatua L. and Phalaris minor Retz are predominant and wide spread in their nature. It has been estimated that losses of crops due to weed competition as a whole throughout the world are greater than those resulting from the combined effect of insect pests and diseases. Weeds may support the development of plant diseases like bacterial and fungal, thus providing shelter for pests of all kinds and act as host plants for plant parasitic nematodes. Thus it is very needful by these several reasons for completely eliminating weeds community from the crop environment. It was reported that with the rising costs of power and labor, the use of herbicides will be the only suitable method to control weed density [6, 7].

In light of the crop losses due to weeds, the present studies were therefore planned and an experiment was conducted at different locations under Adaptive Research zone Sheikhupura with the objective to evaluate different herbicides for controlling narrow leave weeds in wheat.

\section{Materials and methods}

Field experiments were undertaken at three locations: Adaptive Research Farm, Sheikhupura and two at farmer's field during Rabi season 2014-15. The experiment comprised of five treatments replicated three times, using Randomized Complete Block Design (RCBD). A total plot area of 10890 sq. feet was maintained with net plot size of each treatment was $20 \mathrm{x}$ $35 \mathrm{ft}^{2}$. The treatments included four herbicides (Pinoxaden @ 825 ml ha ${ }^{-1}$, Clodinofop propagyle $300 \mathrm{~g} \mathrm{ha}^{-1}$, Fenoxaprop - P-ethyl @ 1235ml ha ${ }^{-1}$, Isoproturon $2000 \mathrm{~g} \mathrm{ha}^{-1}$ ) and weedy check (Table 1). Recommended agronomic cultural practices were applied in all the treatments to raise the crop during the experiment. 
The dose of herbicides applied with the aid of a knap sack sprayer at 55 days after the sowing of wheat crop when weed population was significantly present. All the precautionary procedures were adopted to avoid any herbicides injury while spraying the herbicides treatments.

Data were recorded on plant height at maturity $(\mathrm{cm})$, spike length $(\mathrm{cm})$, weed density $\mathrm{m}^{-2}$ at pre and post application of herbicides, no. of grains spike ${ }^{-1}, 1000$ grain weight (g) and grain yield $\left(\mathrm{kg} \mathrm{ha}^{-1}\right)$. The data were subjected to analysis of variance and the means were compared by the least significant difference test (LSD) at 5\% level of significance [8]. Weed density was calculated with the help of following equation:

$\mathrm{WCE}=\frac{\mathrm{NWC}-\mathrm{NWT}}{\mathrm{NWC}} \times 100 \%$

Where

WCE $=$ Weed Control Efficiency.

$\mathrm{NWC}=$ Number of Weeds $\mathrm{m}^{-2}$ from Control plots (weedy check).

NW T $=$ Number Weeds $\mathrm{m}^{-2}$ in plots Treated with herbicides.

Table 1. Details of herbicides with common name, trade name and recommended dose ha-1 is as under

\begin{tabular}{|l|l|l|l|}
\hline S.No & Common Name & Trade Name & Rate ha $^{-1}$ \\
\hline 1 & Pinoxaden & Axial 50\% EC & $825 \mathrm{ml}$ \\
\hline 2 & Clodinofop- propagyly & Exit 15\% WP & $300 \mathrm{~g}$ \\
\hline 3 & Fenoxa prop-p-ethyl & Brake 75\% EW & $1235 \mathrm{ml}$ \\
\hline 4 & Isoproturon & Proton 50\% WP & $2000 \mathrm{~g}$ \\
\hline
\end{tabular}

\section{Results and discussion} Weeds density $\mathbf{m}^{-2}$

It is an important and key factor in figuring out the effect of treatments on weed growth. The major narrow leaf weeds were Phalaris minor (Birds seed grass) and Avena fatua (wild oats) that infested the experiment at all locations. The analysis of data presented in Table 2 showed that weeds density $\mathrm{m}^{-2}$ was significantly affected by different treatments of herbicides. The data showed that weed density was significantly affected by the integration of Pinoxaden (Axial $50 \%$ EC). The smallest weed density $\mathrm{m}^{-2}$ was recorded at application of treatment $T_{1}$ i.e. Pinoxaden at 55 days after sowing of wheat when significant weed population was present, the mean of weed density $2.0,3.67$ and $1.33 \mathrm{~m}^{-2}$ followed by $12.67,17.67$ and $12.0 \mathrm{~m}^{-2}$ weed density which was recorded from $T_{2}$ (clodinofop) treated plot as compared to weedy check plot at Adaptive Research
Farm, farmer,s field village Jaslani district Nankana and village Ghabran hafizaabd road respectively. Maximum weeds density 51.66, 126.33 and $127.67 \mathrm{~m}^{-2}$ (Table 2) was recorded in weedy check plot at all the three location respectively. The highest weed controlling efficiency was attained by the application of Pinoxaden @ $825 \mathrm{ml} \mathrm{ha}^{-1}$ with $96.12,97.09$ and $98.95 \%$ followed by clodinofop treated plot showing 75.47 , 86.01 and $90.6 \%$ weed control efficiency at Adaptive Research Farm , farmer,s field village Jaslani district Nankana and village Ghabran hafizaabd road respectively (Table $3)$.

The results are in accordance with the results of [9]. These results are also in line with the findings of [10], who managed weeds efficiently in wheat crop with different combination or alone effects of herbicides. 
Table 2. Weed density at before and after application of herbicides against narrow leave weeds of wheat at three different locations under adaptive research zone Sheikhupura during Rabi season 2014-15

\begin{tabular}{|c|c|c|c|c|c|c|}
\hline \multirow[t]{3}{*}{ Treatments } & \multicolumn{6}{|c|}{ Effect of different herbicides on weed density in wheat crop } \\
\hline & \multicolumn{2}{|c|}{ Location.1 } & \multicolumn{2}{|c|}{ Location.2 } & \multicolumn{2}{|c|}{ Location.3 } \\
\hline & $\begin{array}{l}\text { Pre- } \\
\text { treatment }\end{array}$ & $\begin{array}{l}\text { Post- } \\
\text { treatment }\end{array}$ & $\begin{array}{l}\text { Pre- } \\
\text { treatment }\end{array}$ & $\begin{array}{l}\text { Post- } \\
\text { treatment }\end{array}$ & $\begin{array}{l}\text { Pre- } \\
\text { treatment }\end{array}$ & $\begin{array}{l}\text { Post- } \\
\text { treatment }\end{array}$ \\
\hline $\mathrm{T}_{1}$ & $31.33 \mathrm{a}$ & $2.00 \mathrm{~d}$ & $116.00 \mathrm{~A}$ & $3.67 \mathrm{e}$ & $99.33 \mathrm{a}$ & $1.33 \mathrm{e}$ \\
\hline $\mathrm{T}_{2}$ & $33.00 \mathrm{a}$ & $12.67 \mathrm{c}$ & $115.00 \mathrm{~A}$ & $17.67 \mathrm{~d}$ & $100.00 \mathrm{a}$ & $12.00 \mathrm{~d}$ \\
\hline $\mathrm{T}_{3}$ & $30.00 \mathrm{a}$ & $22.00 \mathrm{~b}$ & $116.33 \mathrm{~A}$ & $70.00 \mathrm{~b}$ & $103.00 \mathrm{a}$ & $38.67 \mathrm{c}$ \\
\hline $\mathrm{T}_{4}$ & $30.33 \mathrm{a}$ & $15.00 \mathrm{c}$ & $109.33 \mathrm{~A}$ & $53.33 \mathrm{c}$ & $98.67 \mathrm{a}$ & $53.33 \mathrm{~b}$ \\
\hline \begin{tabular}{|l|}
$\mathrm{T}_{5}$ \\
(weedy check)
\end{tabular} & $32.00 \mathrm{a}$ & $51.66 \mathrm{a}$ & $114.33 \mathrm{~A}$ & $126.33 a$ & $99.00 \mathrm{a}$ & $127.67 \mathrm{a}$ \\
\hline LSD $5 \%$ & NS & 6.13 & NS & 8.31 & NS & 8.30 \\
\hline
\end{tabular}

Means with the same letter are not significantly different

Table 3. Weed control efficiency of different treatments at three locations

\begin{tabular}{|l|c|c|c|}
\hline \multirow{2}{*}{ Treatments } & Location.1 & Location.2 & Location.3 \\
\cline { 2 - 4 } & WCE \% & WCE \% & WCE \% \\
\hline $\mathrm{T}_{1}$ & $96.12 \%$ & $97.09 \%$ & $98.95 \%$ \\
\hline $\mathrm{T}_{2}$ & $75.47 \%$ & $86.01 \%$ & $90.60 \%$ \\
\hline $\mathrm{T}_{3}$ & $57.42 \%$ & $44.58 \%$ & $69.71 \%$ \\
\hline $\mathrm{T}_{4}$ & $70.96 \%$ & $57.78 \%$ & $58.22 \%$ \\
\hline $\mathrm{T}_{5}$ & --- & ----- & --- \\
(weedy check)
\end{tabular}

\section{Effect of different herbicides on different} yield parameters of wheat at three locations

\section{Plant height (cm)}

On the perusal of data it indicated that all the herbicides treated showing significant effects on wheat plant height as compared to weedy check. As in control plot where no herbicide was applied, wheat plants were suppressed due to abundant weeds. Data presented in Table 3 revealed that maximum plant height mean 112.0, 110.07 and 110.5 $\mathrm{cm}$ was recorded from the pinoxaden treated plot followed by $108.67,108.5$ and 107.4 $\mathrm{cm}$ plant heights that obtained in clodinofop treated plot while the minimum plant heights $100.23,99.13$ and $96.83 \mathrm{~cm}$ was obtained in weedy check at three locations i.e. Adaptive Research Farm, farmer's field village Jaslani district Nankana and village Ghabran Hafizaabad road respectively. These results are according to the results of [11] who reported that significant differences ware observed in spike per unit, plant height, grain yield, and biomass with respect to the application time of herbicides. Similarly [12] reported that the smallest plant height was recorded at the control and maximum plant height was obtained with the integration of Topic.

\section{Spike length (cm)}

Highest spike length was recorded from the experimental plot treated with Pinoxaden @ $825 \mathrm{ml} \mathrm{ha}^{-1}$ that remained 12.2, 11.2 and $10.7 \mathrm{~cm}$ (Tables 4, 5, 6) at Adaptive Research Farm, farmer,s field village Jaslani district Nankana and village Ghabran hafizaabd road respectively. In three locations the smallest spike lengths 8.8, 8.1 and $8.9 \mathrm{~cm}$ were obtained from weedy check presented in (Tables 4, 5, 6). Our findings are according to the results of [13]. These results are also comparable with the work of [10]. They reported that maximum spike 
length was achieved by the application of

post- emergence herbicides in wheat crop.

Table 4. Effects of different herbicides on different yield parameters of wheat at adaptive research farm, Sheikhupura

\begin{tabular}{|l|l|l|l|l|l|l|}
\hline Treatments & $\begin{array}{l}\text { Ger. } \\
\text { Count }\left(\mathbf{m}^{-}\right.\end{array}$ & $\begin{array}{l}\text { Plant height } \\
\mathbf{2} \text { (cm) }\end{array}$ & $\begin{array}{l}\text { No. of } \\
\text { productive } \\
\text { tillers }\left(\mathbf{m}^{-2}\right)\end{array}$ & $\begin{array}{l}\text { Spike length } \\
(\mathbf{c m})\end{array}$ & Grains/spike & $\begin{array}{l}\text { '000' grain } \\
\text { weight }(\mathbf{g})\end{array}$ \\
\hline $\mathrm{T}_{1}$ & $164.33 \mathrm{a}$ & $112.00 \mathrm{a}$ & $267.33 \mathrm{a}$ & $12.200 \mathrm{a}$ & $56.667 \mathrm{a}$ & $43.333 \mathrm{ab}$ \\
\hline $\mathrm{T}_{2}$ & $165.67 \mathrm{a}$ & $108.67 \mathrm{~b}$ & $250.33 \mathrm{~b}$ & $10.900 \mathrm{~b}$ & $46.667 \mathrm{~b}$ & $42.000 \mathrm{ab}$ \\
\hline $\mathrm{T}_{3}$ & $163.33 \mathrm{a}$ & $105.20 \mathrm{c}$ & $249.33 \mathrm{~b}$ & $10.633 \mathrm{~b}$ & $46.000 \mathrm{~b}$ & $40.667 \mathrm{~b}$ \\
\hline $\mathrm{T}_{4}$ & $159.00 \mathrm{a}$ & $107.50 \mathrm{~b}$ & $241.67 \mathrm{c}$ & $10.833 \mathrm{~b}$ & $47.667 \mathrm{~b}$ & $41.333 \mathrm{a}$ \\
\hline $\begin{array}{l}\mathrm{T}_{5} \\
\text { (weedy check) }\end{array}$ & $161.33 \mathrm{a}$ & $100.23 \mathrm{~d}$ & $202.33 \mathrm{~d}$ & $8.867 \mathrm{c}$ & $38.000 \mathrm{c}$ & $36.333 \mathrm{c}$ \\
\hline LSD 5\% & $\mathrm{NS}$ & 1.64 & 6.54 & 0.44 & 3.15 & 3.63 \\
\hline
\end{tabular}

Means with the same letter are not significantly different

Table 5. Effect of different herbicides on different yield parameters of wheat village Jaslani tehsil and district, Nankana Sahib

\begin{tabular}{|l|l|l|l|l|l|l|}
\hline Treatments & $\begin{array}{l}\text { Ger. Count } \\
\left(\mathbf{m}^{-2}\right)\end{array}$ & $\begin{array}{l}\text { Plant } \\
\text { height } \\
(\mathbf{c m})\end{array}$ & $\begin{array}{l}\text { No. of } \\
\text { productive } \\
\text { tillers }\left(\mathbf{m}^{-2}\right)\end{array}$ & $\begin{array}{l}\text { Spike length } \\
(\mathbf{c m})\end{array}$ & Grains/spike & $\begin{array}{l}\text { '000' grain } \\
\text { weight }(\mathbf{g})\end{array}$ \\
\hline $\mathrm{T}_{1}$ & $184.00 \mathrm{a}$ & $110.07 \mathrm{a}$ & $236.67 \mathrm{a}$ & $11.167 \mathrm{a}$ & $56.000 \mathrm{a}$ & $34.667 \mathrm{a}$ \\
\hline $\mathrm{T}_{2}$ & $185.33 \mathrm{a}$ & $108.50 \mathrm{ab}$ & $228.33 \mathrm{~b}$ & $10.467 \mathrm{~b}$ & $47.333 \mathrm{~b}$ & $34.333 \mathrm{a}$ \\
\hline $\mathrm{T}_{3}$ & $183.67 \mathrm{a}$ & $100.93 \mathrm{~cd}$ & $214.33 \mathrm{~d}$ & $9.933 \mathrm{c}$ & $41.000 \mathrm{c}$ & $31.667 \mathrm{~b}$ \\
\hline $\mathrm{T}_{4}$ & $184.33 \mathrm{a}$ & $104.40 \mathrm{bc}$ & $221.67 \mathrm{c}$ & $10.267 \mathrm{bc}$ & $44.667 \mathrm{~b}$ & $31.333 \mathrm{~b}$ \\
\hline $\begin{array}{l}\mathrm{T}_{5} \\
\text { (weedy check) }\end{array}$ & $183.00 \mathrm{a}$ & $99.13 \mathrm{~d}$ & $200.00 \mathrm{e}$ & $8.133 \mathrm{~d}$ & $27.667 \mathrm{~d}$ & $29.667 \mathrm{~b}$ \\
\hline LSD 5\% & $\mathrm{NS}$ & 4.12 & 5.81 & 0.34 & 3.19 & 2.06 \\
\hline
\end{tabular}

Means with the same letter are not significantly different

Table 6. Effect of different herbicides on different yield parameters of wheat at village Ghabran Hafizabad Road, tehsil and district Sheikhupura

\begin{tabular}{|l|l|l|l|l|l|l|}
\hline Treatments & $\begin{array}{l}\text { Ger. Count } \\
\left(\mathbf{m}^{-2}\right)\end{array}$ & $\begin{array}{l}\text { Plant height } \\
(\mathbf{c m})\end{array}$ & $\begin{array}{l}\text { No. of } \\
\text { productive } \\
\text { tillers }\left(\mathbf{m}^{-2}\right)\end{array}$ & $\begin{array}{l}\text { Spike length } \\
(\mathbf{c m})\end{array}$ & Grains/spike & $\begin{array}{l}\text { (000' grain } \\
\text { weight }(\mathbf{g})\end{array}$ \\
\hline $\mathrm{T}_{1}$ & $160.33 \mathrm{a}$ & $110.50 \mathrm{a}$ & $269.67 \mathrm{a}$ & $10.700 \mathrm{a}$ & $52.000 \mathrm{a}$ & $42.667 \mathrm{a}$ \\
\hline $\mathrm{T}_{2}$ & $158.00 \mathrm{ab}$ & $107.40 \mathrm{~b}$ & $254.67 \mathrm{~b}$ & $10.233 \mathrm{ab}$ & $49.000 \mathrm{a}$ & $41.667 \mathrm{a}$ \\
\hline $\mathrm{T}_{3}$ & $154.00 \mathrm{abc}$ & $103.33 \mathrm{c}$ & $233.67 \mathrm{c}$ & $9.767 \mathrm{~b}$ & $41.000 \mathrm{c}$ & $40.333 \mathrm{a}$ \\
\hline $\mathrm{T}_{4}$ & $152.00 \mathrm{bc}$ & $105.10 \mathrm{bc}$ & $225.33 \mathrm{~d}$ & $10.100 \mathrm{ab}$ & $45.000 \mathrm{~b}$ & $41.000 \mathrm{a}$ \\
\hline $\begin{array}{l}\mathrm{T}_{5} \\
\text { weedy check })\end{array}$ & $150.67 \mathrm{c}$ & $96.83 \mathrm{~d}$ & $195.00 \mathrm{e}$ & $8.900 \mathrm{c}$ & $29.000 \mathrm{~d}$ & $35.667 \mathrm{~b}$ \\
\hline LSD 5\% & 7.17 & 2.35 & 8.21 & 0.76 & 3.06 & 2.39 \\
\hline
\end{tabular}

Means with the same letter are not significantly different

Number of grain spike ${ }^{-1}$

Number of grains spike ${ }^{-1}$ is an important factor for evaluation of herbicidal effect on wheat yield. It is estimated that increasing the number of grains per spike will increase the spike weight which definitely improves the ultimate yield. All the treatments applied in control significantly increased the number of grains per spike (Tables 4, 5, 6). Among the different herbicides treated plots, highest number of grains per spike mean 56.6, 56.0 and 52.0 were obtained from Pinoxaden 
treated plots at three locations while the minimum number of grains per spike 38.0, 27.6 and 29.0 were recorded in weedy check. The difference, perhaps due to the best elimination of weeds infested the field. These results are in agreement with that of $[14,15]$ who recapped that application of herbicide does have a heavy effect on grains per spike. These findings are also in accordance with the work of $[16,17]$ who reported a significant increase in grains per spike in comparison with the weedy check using the herbicides.

\section{0-grains weight (g)}

Data presented in (Tables $4,5,6$ ) revealed that highest 43.33, 34.67 and 42.67 thousand grains weight was obtained from the plots treated with pinoxaden followed by exit treated plot where 42.00, 34.33 and $41.67 \mathrm{~g}$ thousand grain weight were obtained while the minimum (36.33, 29.67 and $35.66 \mathrm{~g}$ ) 1000- grains weight were recorded from control plot where no herbicide was applied at three locations Adaptive Research Farm , Farmer village Jaslani district Nankana and village Ghabran Hafizaabad road respectively.

\section{Grain yield (kg ha-1)}

Grain yield is the most important parameters to assess the weed control treatments that are applied in experiments. Location wise experimental data regarding grain yield $(\mathrm{kg}$ $\mathrm{ha}^{-1}$ ) is documented in Table 7 which revealed that the all the herbicides had a persuasive effect on the grain yield of wheat crop as compare to control (weedy check). Among the herbicides, the pinoxaden treated plots gave maximum grain yield 2846.7, 3320.0 and $3300.0 \mathrm{~kg} \mathrm{ha}^{-1}$ which were 19.6 , 39.6 and $39.9 \%$ higher than the weedy check $\left(2380.0,2376.7\right.$ and $\left.2358.3 \mathrm{~kg}^{-1}\right)$ at three locations respectively. Our findings are in agreement with that of $[17,18]$ who reported that in fact the application of herbicides greatly affect the grain yield of wheat. Similarly [19] also reported the parallel results. They also reported that different treatments of herbicides increased the grain yield significantly in wheat.

Table 7. Effect of different herbicides on yield of wheat crop sown during Rabi season 2014-15 at three locations under adaptive research zone Sheikhupura

\begin{tabular}{|l|l|l|l|l|l|l|}
\hline \multirow{2}{*}{ Treatments } & \multicolumn{6}{|c|}{ GRAIN YIELD kg ha $\left.^{-1}\right)$} \\
\cline { 2 - 7 } & \multicolumn{2}{|c|}{ LOCATION.1 } & \multicolumn{2}{c|}{ LOCATION.2 } & \multicolumn{2}{c|}{ LOCATION.3 } \\
\cline { 2 - 7 } & Yield & $\begin{array}{l}\text { \% increase/ } \\
\text { decrease }\end{array}$ & Yield & $\begin{array}{l}\text { \% increase/ } \\
\text { Decrease }\end{array}$ & Yield & $\begin{array}{l}\text { \% increase/ } \\
\text { decrease }\end{array}$ \\
\hline $\mathrm{T}_{1}$ & $2846.7 \mathrm{a}$ & $19.6 \%$ & $3320.0 \mathrm{a}$ & $39.6 \%$ & $3300.0 \mathrm{a}$ & $39.9 \%$ \\
\hline $\mathrm{T}_{2}$ & $2663.3 \mathrm{~b}$ & $11.9 \%$ & $3220.0 \mathrm{~b}$ & $35.4 \%$ & $3066.0 \mathrm{~b}$ & $30.0 \%$ \\
\hline $\mathrm{T}_{3}$ & $2586.7 \mathrm{c}$ & $8.70 \%$ & $2866.7 \mathrm{c}$ & $20.6 \%$ & $2890.0 \mathrm{c}$ & $22.5 \%$ \\
\hline $\mathrm{T}_{4}$ & $2500.0 \mathrm{~d}$ & $5.0 \%$ & $2920.0 \mathrm{c}$ & $22.8 \%$ & $2786.7 \mathrm{~d}$ & $18.1 \%$ \\
\hline $\begin{array}{l}\mathrm{T}_{5} \\
\text { (weedy check) }\end{array}$ & $2380.0 \mathrm{e}$ & ---- & $2376.7 \mathrm{~d}$ & ---- & $2358.3 \mathrm{e}$ & ----- \\
\hline LSD 5\% & $\mathbf{6 7 . 3 2}$ & $\mathbf{5 7 . 7 2}$ & $\mathbf{5 2 . 2 4}$ & \\
\hline
\end{tabular}

\section{Conclusion}

In the light of above discussion it is concluded that all the herbicides significantly control the narrow leave weeds in the wheat crop and also improved the grain yield significantly in comparison with the check. Among the herbicides the highest weed control efficiency $(96.12,97.09 \& 98.95 \%)$ and with maximum grain yield of $2846.7,3320.0 \& 3300.0 \mathrm{~kg} \mathrm{ha}^{-1}$ which is $19.6,39.6 \& 39.9 \%$ higher than weedy check were recorded in the penoxadin treated plot at three locations respectively.

\section{Authors' contributions}

Conceived and designed the experiments: MQ Waqar \& G Nabi, Performed the experiments: M Shahbaz, M Sajjad \& M Riaz, Analyzed the 
data: F Ahmad, Contributed reagents/ materials/ analysis tools: MQ Waqar, Wrote the paper: S Muhammad \& M Anwar.

\section{References}

1. Anonymous (2015). Agriculture Statistics of Pakistan. Ministry of Food, Agriculture and Livestock (MINFAL), Islamabad. Government of Pakistan, Economic Survey of Pakistan p. 28

2. Savary S, Srivastava RK, Singh HM \& Elazegui FA (1997). A characterisation of rice pests and quantification of yield losses in the rice-wheat system of India. Crop Protect 16: 387-398.

3. Savary S, Willocquet L, Elazegui FA, Castilla NP \& Teng PS (2000). Rice pest constraints in tropical Asia: quantification of yield losses due to rice pests in a range of production situations. Plant Dis 84: 357369.

4. Barros JFC, Basch G \& de-Carvalho $M$ (2008). Effect of reduced doses of a postemergence graminicide to control Avena sterilis L. and Lolium rigidum G. in no-till wheat under Mediterranean environment. Crop Protec 27: 1031-1037.

5. Taj FH, Khattak A \& Jan T (1986). Chemical weed control in wheat. Sarhad J Agric (2):15- 21.

6. Young FL, Ogg AG, Young DL \& Papendick RI (1996). Weed management for crop production in the northwest wheat region. Weed Sci 44(2): 429-436.

7. Norris RF (1982). Interactions between weeds and other pests in the agro ecosystem. P. 343-406. In J. L. Hatfield and I. J. Thomson (ed.) Proc. Conf. on Biometeorology in integrated pest management, Univ. California, Davis, CA, 15-17 July, 1980. Academic press New York.

8. Steel RGD \& Torrie JH (1980). Principles and procedures of statistics- a biological approach. McGraw Hill Book Co Inc New York.

9. Tunio SD, Kaka SN, Jarwar AD \& Wagan MR (2004). Effect of integrated weed management practices on wheat yield. Pak J Agric Engg Vet Sci 20(1): 5-10.

10. Khalil SK, Khan AZ, Shah P, Baloch AR \& Malik MF (1999). Herbicides and row spacings effect on leaf characteristics and grains spike ${ }^{-1}$ of wheat. Sarhad J Agric 16(1): 13-17.

11. Haile D \& Girma F (2010). Integrated effect of seeding rate, herbicide dosage and application timing on durum wheat (Triticum turgidum L. Var Durum) yield, yield components and wild oat (Avena fatua L.) Control in South Eastern Ethiopia 2: 12-26.

12. Mitiku A \& Dalga D (2014). Integration of seed rate with herbicide application time for the management of weed dynamics and increment of bread wheat (triticum aestivum L.) yield at south eastern part of Ethiopia. British Journal of Research 1(2): 035-042.

13. Hassan G, Khan I, Khan H \& Munir M (2005). Effect of different herbicides on weed density and some agronomic traits of wheat. Pak J Weed Sci Res 11(1-2): 17-22.

14. Khan MA, Marwat KB, Hassan G \& Khan $N$ (2002). Impact of weed management in maize planted at night. Pak J Weed Sci Res 8(1-2): 57-62.

15. Khan MH, Hassan G, Khan N \& Khan MA (2003). Efficacy of different herbicides for controlling broadleaf weeds in wheat. Asian J Plant Sci 2(3): 254-256.

16. Cheema MS \& Akhtar M (2005). Efficacy of different post emergence herbicides and their application methods in controlling weeds in wheat. Pak J Weed Sci Res 11(12): 23-30.

17. Arif M, Awan L \& Khan HU (2004). Weed management strategies in wheat (Triticum aestivum L.). Pak J Weed Sci Res 10(1-2): 11-16.

18. Hassan G, Faiz B, Marwat KB \& Khan M (2003). Effects of planting method and tank mixed herbicides on controlling grassy and broadleaf weeds and their effect on wheat cv Fakhr-e-Sarhad. Pak J Weed Sci Res 9: 1-11.

19. Hashim S, Marwat KB \& Hassan G (2002). Response of wheat varieties to substituted urea herbicides. Pak J Weed Sci Res 8(1-2): 49-56. 